\title{
Perlindungan Profesi Guru Atas Kekerasan Yang Dilakukan Oleh Siswa
}

\author{
Yehezkiel Eka Laoh ${ }^{\text {a, }}{ }^{*}$, Wenly RJ Lolong ${ }^{\text {b, } 2}$ \\ a Universitas Negeri Manado, Program Studi Ilmu Hukum, Manado, Indonesia \\ ${ }^{\mathrm{b}}$ Universitas Negeri Manado, Program Studi Ilmu Hukum, Manado, Indonesia \\ ${ }^{1}$ yehezkiellaoh1650@gmail.com*; wenly.lolong@unima.ac.id; \\ *wenly.lolong@unima.ac.id
}

\begin{tabular}{ll}
\hline Informasi artikel & ABSTRAK \\
\hline Sejarah artikel: & Saat ini, terdapat banyak kasus kekerasan yang menimpa guru yang \\
Diterima: & dilakukan oleh siswa. Perlindungan hukum sangat diperlukan dalam \\
06 Desember 2020 & memberikan keamanan dan kenyamanan bekerja bagi guru. \\
Disetujui: & Permasalahan penelitian ini yang pertama terkait modus perbuatan \\
10 Desember 2020 & kekerasan yang dilakukan oleh siswa terhadap guru. Kedua, prinsip \\
\hline Kata kunci: & hukum yang perlu diperhatikan dalam proses penegakan hukum dalam \\
Perlindungan & kasus kekerasan yang dilakukan siswa terhadap guru. Tujuan penelitian \\
Guru & ini mengetahui perlindungan hukum bagi guru atas tindak kekerasan. \\
Kekerasan & Metode penelitian yang digunakan penelitian hukum normatif. Hasil \\
Siswa & penelitian menjelaskan bahwa modus perbuatan kekerasan terhadap guru \\
& meliputi perbuatan perundungan, penganiayaan, maupun pembunuhan. \\
& Prinsip hukum yang perlu diperhatikan dalam penegakan hukum atas \\
& kasus kekerasan terhadap guru oleh siswa meliputi prinsip hak anak yang \\
& melekat pada diri individu sang siswa sebagai anak, prinsip keadilan \\
& restoratif dan serta konsep diversi. Dari sisi guru prinsip hukum meliputi \\
& prinsip kesetaraan dihadapan hukum serta prinsip perlindungan atas \\
& pekerjaan maupun perlindungan atas kebebasan pribadi.
\end{tabular}

\section{Keywords: \\ Protection \\ Teacher \\ Violence \\ Students}

\begin{abstract}
ABSTRAK dilakukan oleh siswa. Perlindungan hukum sangat diperlukan dalam memberikan keamanan dan kenyamanan bekerja bagi guru. Permasalahan penelitian ini yang pertama terkait modus perbuatan kekerasan yang dilakukan oleh siswa terhadap guru. Kedua, prinsip hukum yang perlu diperhatikan dalam proses penegakan hukum dalam kasus kekerasan yang dilakukan siswa terhadap guru. Tujuan penelitian ini mengetahui perlindungan hukum bagi guru atas tindak kekerasan. Metode penelitian yang digunakan penelitian hukum normatif. Hasil penelitian menjelaskan bahwa modus perbuatan kekerasan terhadap guru meliputi perbuatan perundungan, penganiayaan, maupun pembunuhan. kasus kekerasan terhadap guru oleh siswa meliputi prinsip hak anak yang melekat pada diri individu sang siswa sebagai anak, prinsip keadilan restoratif dan serta konsep diversi. Dari sisi guru prinsip hukum meliputi pekerjaan maupun perlindungan atas kebebasan pribadi.
\end{abstract}

\begin{abstract}
Teacher Profession Protection against student's violence. Nowadays, there are many cases of student's violence against teachers. Legal protection is needed to provide safe and comfort work area for teachers. The first problem of this research is the mode of student violence against the teachers. Second, the legal principles to be considered in the law enforcement process of violence perpetrated by students against teachers. The purpose of this study to determine the legal protection for violence against teachers. The research method used is normative legal research. The results showed that the mode of violence against teachers included bullying, assault, and murder. Legal principles need to be considered in law enforcement of students violence against teachers include the principle of child rights inherent in the individual student as a child, the principle of restorative justice, and the concept of diversion. The law principle from the teacher's point of view includes, the principle of equality before the law as well as the principle of protection of work and protection of individual freedom.
\end{abstract}

Copyright (C) 2020 Yehezkiel Eka Laoh. All Right Reserved

\section{Pendahuluan}

Tujuan kehadiran pemerintahan negara secara nyata tercantum dalam Pembukaan Undang-Undang Dasar Negara Republik Indonesia 1945 alinea ke-4 (empat) yang berbunyi "Melindungi segenap bangsa Indonesia dan seluruh tumpah darah Indonesia, memajukan 
kesejahteraan umum, mencerdaskan kehidupan bangsa dan ikut melaksanakan ketertiban dunia". Perlindungan terhadap segenap bangsa Indonesia harus dimaknai sebagai perlindungan yang tidak bisa hanya merujuk pada komponen masyarakat namun meliputi pula masingmasing individu warga negara Indonesia. Pada konteks ini maka dalam pengertian perlindungan terhadap individu ini maka menjadi pertanyaan kemudian apakah profesi termasuk hal yang seharusnya turut mendapat perlindungan.

Pertanyaan berikutnya ialah jika kemudian profesi merupakan hal yang layak mendapat perlindungan, maka bagaimanakah dengan profesi guru? Apakah profesi guru merupakan hal yang turut memerlukan perlindungan negara? Terhadap pertanyaan ini maka secara ideal tentu dapat dijawab sebagai sesuatu yang mutlak ketika guru mendapatkan perlindungan. Namun demikian apa dan bagaimana konsep model perlindungan guru ini perlu ditelaah lebih jauh.

Guru dalam kehadirannya merupakan pendidik professional yang mempunyai tugas pokok untuk mendidik, mengajar, membimbing, mengarahkan, melatih, menilai, serta kemudian mengevaluasi peserta didik untuk pendidikan anak usia dini jalur pendidikan formal, pendidikan dasar, juga pendidikan menengah. Hal ini termuat dalam Undang-Undang Nomor 14 Tahun 2005 tentang Guru dan Dosen (UUGD). Kehadiran produk hukum sesuai cita-cita idealnya ialah salah satunya untuk melindungi profesi guru. Namun demikian berdasarkan fakta dilapangan kehadiran produk hukum ini dalam kenyataan belum cukup mampu mewujudkan cita-cita kehadiran dimaksud.

Kekerasan merupakan satu istilah yang tidak asing ditelinga kita dan ketika kita mendengar kata kekerasan. Fenomena kekerasan saat ini telah mewarnai hampir seluruh aspek kehidupan social kita baik politik, budaya, bahkan hingga dunia pendidikan (Martono, 2012). Kekerasan terhadap guru akhir-akhir ini terus merebak terjadi disekitar kita. Peristiwa pembunuhan terhadap guru yang terjadi di Manado pada tahun 2019 menjadi contoh terkini terhadap betapa penting implementasi optimal pengaturan terhadap perlindungan guru. Kasus pembunuhan dimaksud terjadi di SMK Ichtus Manado Sulawesi Utara, dimana seorang guru dibunuh siswanya hanya karena menegur siswa itu yang merokok dalam lingkungan sekolah (Ikanubun, 2019).

Setahun sebelumnya yakni tahun 2018 terdapat pula kasus kekerasan terhadap seorang Guru Seni Rupa di Madura Jawa Timur yang dilakukan oleh siswa. Pemukulan yang dilakukan oleh siswa dalam kasus tersebut mengakibatkan sang Guru akhirnya meninggal dunia setelah sebelumnya dilarikan ke rumah sakit (Jajeli, 2018). Diluar kasus ini maka dapat disebut disini beberapa kasus kekerasan lain (non pembuhuhan) misalnya terjadi di Kendal Jawa Tengah saat seorang guru didorong oleh para siswa di dalam kelas. Videonya kemudian viral di publik (Purbaya, 2018).

Pembiaran terhadap kondisi ini tentu saja merupakan hal yang tidak diinginkan terutama bagi individu warga negara yang memiliki profesi sebagai guru. Pada kondisi demikian maka hal ini tentu saja berdampak negatif secara psikologis terhadap guru. Guru akan merasa kehilangan kewibawaannya di sekolah dalam melakukan pengajaran. Efeknya berimbas kepada sikap, perilaku dan moral siswa dalam kesehariannya seperti siswa akhirnya berani melawan guru, bahkan siswa tidak takut apapun dalam kesehariannya.

Di luar daripada itu guru akan merasa tidak aman dan nyaman dalam melakukan dan menjalankan tugas pokok dan fungsinya. Guru dapat dengan mudah terintimidasi baik dari dirinya sendiri maupun dari pihak luar serta kondisi lingkungan sekolah yang ada. Sementara itu dari pihak siswa peristiwa-peristiwa diatas dapat mendorong hadirnya persepsi buruk terhadap profesi guru.

Kehadiran negara dalam hal ini pemerintah untuk melindungi profesi guru merupakan sesuatu hal yang sifatnya mutlak. Pengaturan hukum merupakan sarana menghadirkan ketertiban dalam kehidupan masyarakat termasuk dalam konteks permasalahan ini. Di tengah terjadinya peristiwa-peristiwa diatas maka hadir pertanyaannya kemudian yakni bagaimana sebenarnya keberadaan hukum di Indonesia mampu memberikan solusi terhadap keadaan ini. 
Berdasarkan kondisi diatas maka dirumuskan permasalahan disini ialah pertama, bagaimanakah modus perbuatan kekerasan yang dilakukan oleh siswa terhadap guru? Kedua, apakah prinsip hukum yang perlu diperhatikan dalam proses penegakan hukum dalam kasus kekerasan yang dilakukan siswa terhadap guru?

\section{Metode}

Penelitian ini termasuk dalam jenis penelitian hukum normatif (Soekanto, 2000). Penelitian hukum normatif mengkaji hukum yang dikonsepkan sebagai norma atau kaidah yang berlaku. Dalam penelitian ini mengkaji aturan-aturan hukum, konsep-konsep hukum untuk menganalisa penegakan hukum atas tindak pidana yang dilakukan oleh siswa terhadap guru. Dalam penelitian ini, penulis menggunakan pendekatan peraturan perundang-undangan dan pendekatan kasus.

Pendekatan peraturan perundang-undangan adalah pendekatan yang dilakukan dengan menelaah semua undang-undang dan regulasi sebagai bahan acuan dasar dalam melakukan penelitian terkait dengan isu hukum yang ditangani. Pendekatan kasus adalah pendekatan yang dilakukan dengan cara melakukan telaah terhadap kasus-kasus yang berkaitan dengan isu yang dihadapi yang telah menjadi putusan pengadilan yang telah mempunyai kekuatan hukum yang tetap (Marzuki, 2009). Sumber bahan hukum mencakup sumber bahan hukum primer, sekunder dan tersier.

\section{Hasil dan Pembahasan}

\section{Modus Perbuatan Kekerasan Siswa Terhadap Guru}

Perlindungan hukum adalah segala upaya pemenuhan hak dan pemberian bantuan untuk memberikan rasa aman kepada saksi dan atau korban, yang dapat diwujudkan dalam bentuk seperti melalui restitusi, kompensasi, pelayanan medis, dan bantuan hukum (Soerjono, 1984). Sedangkan Satjipto Raharjo mengemukakan bahwa perlindungan hukum adalah memberikan pengayoman terhadap hak asasi manusia (HAM) yang dirugikan orang lain dan perlindungan itu di berikan kepada masyarakat agar dapat menikmati semua hak-hak yang diberikan oleh hukum (Rahardjo, 2000). Karena sifat sekaligus tujuan hukum menurutnya adalah memberikan perlindungan (pengayoman) kepada masyarakat, yang harus diwujudkan dalam bentuk adanya kepastian hukum. Perlindungan hukum merupakan tindakan bagi yang bersifat preventif dan represif (Hadjon, 1987).

Hukum sendiri memiliki fungsi menyelesaikan setiap masalah sosial dan menangani persoalan kemanusiaan (Subiharta, 2015). Hukum dalam fungsi tersebut bergantung pada berjalannya elemen-elemen yang ada didalam hukum itu sendiri sebagai sebuah sistem (Nurhadianto, 2015). Inilah yang kemudian dinamakan dengan sistem hukum yang didalamnya terdiri dari elemen peraturan hukum, penegak aturan tersebut dan masyarakat itu sendiri.

Terkait dengan preventif dan represif sebagai sarana perlindungan hukum maka diartikan oleh Hadjon sebagai berikut:

a. Sarana Perlindungan Hukum Preventif. Pada perlindungan hukum preventif ini, subyek hukum diberikan kesempatan untuk mengajukan keberatan atau pendapatnya sebelum suatu keputusan pemerintah mendapat bentuk yang definitif. Tujuannya adalah mencegah terjadinya sengketa.

b. Sarana Perlindungan Hukum Represif. Perlindungan hukum yang represif bertujuan untuk menyelesaikan sengketa. Penanganan perlindungan hukum oleh Pengadilan Umum dan Pengadilan Administrasi di Indonesia termasuk kategori perlindungan hukum ini. Prinsip kedua yang mendasari perlindungan hukum terhadap tindak pemerintahan adalah prinsip negara hukum. Dikaitkan dengan pengakuan dan perlindungan terhadap hak-hak asasi manusia, pengakuan dan perlindungan terhadap hak-hak asasi manusia mendapat tempat utama dan dapat dikaitkan dengan tujuan dari negara hukum (Hadjon, 1987). 
Berdasarkan kerentanan situasi dan kondisi yang ada seperti diuraikan dalam bagian awal tulisan ini, maka profesi guru jelas memerlukan perlindungan hukum. Perlindungan hukum disini tidak semata sebagai bentuk perlindungan hak, namun merujuk pula kepada perlindungan kepada kemanusiaan itu sendiri. Diluar daripada itu keberadaan guru dalam tugasnya berada dalam konteks menjalankan amanat konstitusi yakni mencerdaskan kehidupan bangsa.

Perlindungan profesi guru secara hukum seharusnya dimaknai sebagai kewajiban oleh negara untuk melindungi warga negara yang memiliki profesi mulia. Profesi mana hal tersebut termaktub sebagai salah satu tujuan negara yang termuat dalam konstitusi negara ini. Aspek kepastian hukum menjadi sedemikian penting dalam kehadirannya untuk menjamin kenyamanan menjalankan profesi guru.

Kepastian perlindungan terhadap guru mutlak untuk memberikan kenyamanan bekerja. Lingkungan sosial tempat bekerja yang mendukung kenyamanan guru dalam melaksanakan tugas menjadi hal yang pokok (Sanchez-Danday, 2019). Padahal keberadaan guru begitu signifikan tidak hanya untuk konteks pengetahun anak didik namun bahkan membangun kemanusiaan itu sendiri. Dalam hal ini guru berperan untuk menghadirkan pemahaman yang utuh dan benar lewat pendidikan terhadap apa yang dimaksud dengan hak asasi manusia sebagai bagian kesadaran terhadap eksistensi kemanusiaan itu sendiri (Musheer \& Shakir, 2017).

Soetjipto menyatakan bahwa profesi Guru berada dalam konteks bahwa profesi ini merupakan bagian dari pelayanan terhadap masyarakat. Dimana hal tersebut dipandang sebagai karier yang akan dilaksanakan sepanjang hayat (Soetjipto \& Kosasih, 2009). Konsep pelayanan terhadap masyarakat ini membawa profesi guru dipandang sebagai profesi yang sangat mulia dimana olehnya mendapat kedudukan tinggi dalam struktur sosial masyarakat terkait profesi.

Warsono menyebut bahwa profesi guru sangat terkait dengan profil manusia yang memiliki keteladanan, ilmuwan, motivator, intelek, dan bijak bagi peserta didik (Warsono, 2017). Faktanya beban peningkatan mutu pendidikan seringkali ditimpakan sebagian besarnya ada dipundak guru. Padahal dalam kerangka ini guru dituntut untuk memiliki profesionalisme yang tinggi dalam menjalankan tugasnya. Pengembangan profesi guru maupun peningkatan kualitas individu sebagai guru dalam kenyataan terus menjadi perhatian pemerintah (Putri \& Imaniyati, 2017).

Persoalannya kemudian kekerasan yang terus terjadi terhadap guru dalam kenyataan mengancam eksistensi profesi ini. Optimalisasi kinerja secara individu maupun dari aspek profesionalitas profesi jelas akan sangat terganggu pencapaiannya ketika kekerasan terus terjadi terhadap guru. Pembiaran terhadap hal ini dapat berdampak pada penurunan kualitas pendidikan itu sendiri. Sebab aktor penting dalam berjalannya pendidikan justru merasa tidak nyaman dalam melaksanakan tugas kerjanya.

Beberapa jenis kekerasan yang umum dialami guru misalnya perundungan, penganiayaan dan pembunuhan. Untuk Perundungan (Bullying) terdapat contoh kasus misalnya yang terjadi di Gresik, Jawa Timur. Dimana seorang siswa yang sengaja melakukan tindakan perundungan terhadap guru yang bernama Nur Kalim di salah satu SMP di Gresik, Jawa Timur. Sang guru dicekik lehernya oleh siswa sebagai akibat teguran terhadap siswa yang merokok oleh guru tersebut (Purwasatria, 2019). Untuk perundungan sendiri jika tidak dilakukan secara fisik maka sering pula terjadi serangan secara non fisik. Diantaranya meliputi ancaman pembunuhan. Dalam contoh kasus misalnya terhadap seorang guru di Kepahiang yang diancam dibunuh oleh siswanya karena masalah yang sebenarnya sepele yakni adanya teguran terhadap pelanggaran aturan sekolah terkait larangan mengecat pirang rambut. Teguran mana tidak diterima oleh siswa dimaksud (Anonymous, 2018).

Faktor-faktor yang melatar belakangi tindakan kekerasan atau kriminalisasi terhadap pendidik (Guru) dan tenaga kependidikan lainnya menurut Saihu dan Taufik, meliputi:

(1) Adanya pemahaman yang tidak utuh bagi orang tua siswa dan masyarakat pada umumnya terhadap Undang-Undang Perlindungan Anak yang pada prinsipnya mengatur anak dan keberadaannya yang wajib mendapatkan perlindungan. 
(2) Adanya kesalah pahaman dari orang tua siswa terhadap apa yang dilakukan oleh guru dalam mendisiplinkan siswanya di sekolah, dan atau siswa terhadap siswa, yang disebabkan karena perkelahian diantara mereka;

(3) Komunikasi yang tidak utuh antara fakta kejadian di sekolah dengan laporan siswa kepada orang tua, dan orang tua tidak mencari kebenarannya karena ketidak pahamannya terhadap pola pendidikan ataupun karena kesewenang-wenangannya;

(4) Kegiatan proses belajar mengajar yang tidak maksimal. Hal ini biasanya disebabkan guru sibuk dengan urusan administrasi pembelajaran atau karena adanya tugas lain yang harus dikerjakan baik di lingkungan sekolah seperti mengerjakan beberapa tugas ketata usahaan maupun di luar sekolah berupa menghadiri acara pelatihan dan lain sebagainya;

(5) Minimnya pemahaman orang tua terhadap pola pendidikan. Biasanya kasus-kasus ini terjadi akibat ketidak pedulian orang tua terhadap perkembangan belajar siswa dan belum memahami peraturan sekolah dengan baik (Saihu \& Taufik, 2019).

Guru dalam hal ini sesungguhnya berada dalam posisi yang rentan. Kekerasan maupun ancaman kekerasan berpotensi mengganggu optimalisasi kinerja guru dalam melaksanakan tugasnya (Dzuka \& Dalbert, 2007). Isu kekerasan terhadap guru bahkan tidak hanya dikaji dalam konteks hukum namun saat ini telah terdorong sebagai isu dibidang kesehatan masyarakat (Longobardi et al., 2019). Betapa fakta ini menegaskan sedemikian pentingnya persoalan kekerasan terhadap guru.

Sementara itu dari sisi lainnya guru dalam menjalankan tugas tanggungjawabnya cukup sering juga terdengar diadukan oleh orang tua muridnya bahkan siswanya sendiri dengan tuduhan melanggar Undang-undang Perlindungan Anak. Semenjak kehadiran Undang-Undang Nomor 23 Tahun 2002 tentang Perlindungan Anak yang telah diubah dengan Undang-Undang Nomor 35 Tahun 2014 maka terdapat pasal yang umum untuk dijadikan dasar pengaduan dalam produk hukum ini. Adapun jenis-jenis kekerasan tercantum pada pasal 69, yaitu kekerasan fisik, psikis, dan seksual. yaitu kekerasan fisik, psikis, dan seksual (Kharis \& Liany, 2017).

Dari kondisi ini sesungguhnya posisi dan kedudukan guru dalam menjalankan profesinya sangatlah rentan dari sisi hukum. Keberadaan produk hukum yang secara khusus mampu melindungi guru agar dapat merasa aman dan nyaman menjalankan tugas kerjanya merupakan hal yang sangat penting. Menurut Faisal dan Jawade, perlindungan yang diperlukan oleh guru diantaranya meliputi, perlindungan hukum, profesi dan perlindungan keselamatan dan kesehatan kerja (Faisal \& Jawade, 2019). Sementara saat ini dapat dikatakan bahwa UndangUndang Guru dan Dosen yang menjadi dasar hukum keberadaan profesi guru nampaknya belum cukup mendetail pengaturan terkait perlindungan hukum dimaksud.

Secara nyata bentuk perbuatan kekerasan siswa terhadap guru yang umum terjadi maupun berpotensi terjadi meliputi jenis kekerasan terbuka, kekerasan tertutup, serta kekerasan seksual. Untuk kekerasan terbuka dapat dirinci seperti dipaksa terlibat untuk berkelahi, dipukul, ditendang, didorong bahkan dibunuh. Dalam konteks ini kekerasan terbuka jenis-jenis perbuatannya termasuk kepada tindakan penganiayaan.

Sementara untuk kekerasan tertutup sebagai bentuk kekerasan yang banyak kali menimpa guru dilapangan meliputi ancaman maupun cemoohan. Hal mana dalam kenyataan menyebabkan kondisi psikis guru mengalami gangguan. Sehingga hak atas rasa nyaman sebagai bagian dari hak asasi yang dijamin undang-undang menjadi terlanggar. Ironisnya pelanggarnya justru ialah orang yang masih dibawah umur.

Diluar dari pada dua bentuk kekerasan ini maka potensi kekerasan dapat juga terjadi dalam bentuk kekerasan seksual. Bentuk kekerasan seksual secara umum meliputi perbuatan secara fisik maupun secara verbal. Perbuatan kekerasan seksual secara verbal sering tidak teridentifikasi dengan baik sebagai kekerasan seksual misalnya gurauan, ekspresi wajah, gestur tubuh, serta bentuk ungkapan kata-kata maupun pernyataan yang merujuk pada konten seks.

Berkembangnya media internet turut mempengaruhi perubahan modus perbuatan kekerasan dimaksud. Terkecuali kekerasan fisik, maka kekerasan psikis maupun seksual rentan

20| Jurnal Civic Educatioan: Media Kajian Pancasila dan Kewarganegaraan 
terjadi pada konteks kasus kekerasan terhadap guru yang proses terjadinya dilakukan melalui media internet. Bila ini kemudian terjadi maka terhadap pelakunya sesungguhnya dapat dikenakan ancaman pidana sebagaimana diatur lewat Undang-Undang Informasi dan Transaksi Elektronik.

Persoalannya kemudian ialah adanya hambatan-hambatan teknis penegakan hukum yang tidak lain seringkali justru dimulai dari substansi hukum itu sendiri. Dalam konteks ini keadilan akan cukup jauh dari sanubari guru ketika dihadapkan pada kenyataan bahwa pelaku merupakan siswa yang secara umur berada dalam kategori anak. Sehingga perlakuannya menjadi berbeda berdasarkan adanya Undang-Undang Perlindungan Anak maupun Undang-Undang Sistem Peradilan Pidana Anak.

\section{Prinsip-Prinsip Hukum Yang Perlu Diperhatikan Dalam Penyelesaian Perkara Pidana Kekerasan Siswa Terhadap Guru}

Secara umum ketika terjadi kasus pidana yang melibatkan anak tahapan penyelesaiannya meliputi tahap penangkapan sampai tahap putusan pengedilan, Penyidik, Penuntut Umum, Hakim, Pembimbing Kemasyarakatan, Advokat atau pemberi bantuan hukum lainnya, dan petugas lain dalam memeriksa perkara Anak, Anak Korban, dan/atau Anak Saksi tidak memakai toga atau atribut kedinasan (Undang-Undang Nomor 11 Tahun 2012 Tentang Sistem Peradilan Pidana Anak, 2012). Sementara itu dalam beberapa penyelesaian kasus, seringkali siswa yang melakukan penganiayaan terhadap guru hanya mendapat hukuman ringan dikarenakan dengan adanya Undang-Undang Nomor 35 Tahun 2014 tentang Perlindungan Anak. Padahal dalam Pasal 27 ayat (1) UUD 1945 menegaskan bahwa semua warga negara bersamaan kedudukannya didalam hukum (equality before the law). Kesamaan dihadapan hukum berarti setiap warga negara harus diberlakukan sama dalam setiap permasalahan yang terjadi.

Dalam kasus pidana yang melibatkan anak maka hadirnya Undang-Undang Nomor 11 Tahun 2012 tentang Sistem Peradilan Pidana Anak membawa nuansa baru terhadap penyelesaian hukum atas kejahatan yang dilakukan anak. Diversi hadir sebagai salah satu bentuk penyelesaian perkara pidana anak. Diversi adalah suatu pengalihan penyelesaian perkara anak dari proses peradilan pidana ke proses diluar peradilan pidana (Undang-Undang Nomor 11 Tahun 2012 Tentang Sistem Peradilan Pidana Anak, 2012).

Hal ini memang dapat dikatakan sudah sejalan dengan konsep ultimum remedium dari hukum pidana. Sebagaimana ditegaskan oleh Sudarto bahwa hukum pidana dikenal sebagai ultimum remidium. Hal ini berarti bahwa hukum pidana hanya merupakan alat terakhir apabila usaha-usaha lain tidak bisa dilakukan (Soetiyono, 2005). Hukum pidana adalah bagian dari keseluruhan hukum yang berlaku di suatu negara (Moeljatno, 1984).

Namun demikian dalam konteks terjadinya kekerasan yang dianggap sebagai sebuah kejahatan maka hukum pidana Indonesia cukup tegas mengaturnya. Terkait hal ini Kitab Undang-Undang Hukum Pidana mengatur dalam Pasal 351 tentang tindak pidana penganiayaan diatur dalam Pasal 351 KUHP dan dalam Pasal 338 tentang Pembunuhan maupun dalam Pasal 340 tentang Pembunuhan Berencana.

Secara ideal dalam konsepsi hukum pidana tiada seorang pun yang dapat lepas dari tuntutan hukuman ketika melakukan kejahatan. Anak sebagai pelaku kejahatan tentu harus dihukum, walaupun memang terdapat rambu-rambu baik yang berkaitan dengan asas perlindungan anak maupun implementasi ketentuan peraturan perundang-undangan yang khusus mengatur tentang perlindungan anak.

Terkait dengan hal penghukuman terhadap anak maka secara prinsip seyogyanya tetap harus memperhatikan 4 prinsip umum hak anak sebagaimana tercantum dalam Konvensi Hak Anak yang mencakup prinsip non diskriminasi (non discrimination); prinsip kepentingan terbaik bagi anak (the best interest of the child); prinsip hak untuk hidup, kelangsungan hidup, dan perkembangan; prinsip penghargaan terhadap pendapat anak. 
Selain daripada adanya Konvensi Hak Anak dengan 4 (empat) prinsip umum hak anak dimaksud maka terdapat pula Beijing Rules yang dikeluarkan oleh PBB dan disahkan lewar Resolusi Majelis Umum PBB No. 40 / 33 tanggal 29 November 1985 (Paulus Hadi Suprapto \& Atmasasmita, 1997). Tujuan utama dari sistem peradilan pidana ini telah ditegaskan dalam Beijing Rules. Dalam rule 5.1 disebutkan bahwa bertujuan untuk memajukan kesejahteraan anak dan mengedepankan prinsip proporsionalitas (Zulfa \& Zihaningrum, 2015).

Anak dalam konsep sebagai individu manusia yang dianggap memerlukan perlindungan khusus menjadi dasar hadirnya instrumen internasional. Sebagai dampak dari adanya Beijing Rules, maka penyelesaian perkara anak dapat dilakukan lewat jalur diversi. Konsep diversi hadir dalam maksud untuk menghindari dampak negatif pada anak yang ditimbulkan saat proses peradilan pidana (Zulfa \& Zihaningrum, 2015).

Diversi merupakan konsep yang dihadirkan dalam maksud pertama, untuk menghindarkan anak dari penahanan. Kedua, untuk menghindari cap/label anak sebagai penjahat. Ketiga, untuk mencegah pengulangan tindak pidana yang dilakukan oleh anak, agar anak bertanggung jawab atas perbuatannya; Keempat, untuk melakukan intervensi-intervensi yang diperlukan bagi korban dan anak tanpa harus melalui proses formal, dan menjauhkan anak dari pengaruh dan implikasi negatif dari proses peradilan.

Selain dari pada diversi maka konsep keadilan restoratif merupakan prinsip pokok yang menjadi rambu-rambu dalam konteks penyelesaian perkara pidana anak. Keadilan restoratif (restorative justice) sendiri sejatinya merupakan prinsip penyelesaian perkara tindak pidana yang melibatkan pelaku, korban, keluarga pelaku/korban, dan pihak lain yang terkait untuk bersama-sama mencari penyelesaian yang adil dengan menekankan pemulihan kembali pada keadaan semula, dan bukan pembalasan (Undang-Undang Nomor 11 Tahun 2012 Tentang Sistem Peradilan Pidana Anak, 2012).

Dalam konteks penyelesaian kasus kekerasan terhadap guru yang dilakukan oleh siswa maka siswa yang dalam hal ini berada dalam usia anak dengan demikian tunduk pada sistem peradilan pidana anak. Keberadaan prinsip keadilan restoratif serta diversi dalam penyelesaian perkara kekerasan terhadap anak merupakan hal yang mutlak diterapkan. Walaupun memang keberadaan dua prinsip ini tidak berada dalam maksud untuk membebaskan siswa dari tanggungjawabnya secara hukum atas perbuatan pidana yang telah dilakukannya. Pada konteks ini perlu diingat bahwa terdapat prinsip tanggung jawab pidana termuat tegas dalam Pasal 2 Kitab Undang-Undang Pidana yang menyebut bahwa ketentuan pidana dalam perundangundangan Indonesia diterapkan bagi setiap orang yang melakukan sesuatu tindak pidana di Indonesia (Soesilo, 1991).

Sementara itu dari sisi Guru, prinsip kesetaraan dihadapan hukum serta prinsip perlindungan atas pekerjaan maupun perlindungan atas kebebasan pribadi diletakkan menjadi dasar bagi perlindungan profesi Guru itu sendiri. Perlindungan hak asasi manusia secara implementatif terjabarkan pada Undang-Undang Nomor 39 Tahun 1999 tentang Hak Asasi Manusia. Keberadaan Undang-Undang Nomor 39 Tahun 1999 tentang Hak Asasi Manusia ini akan bersanding dengan Undang-Undang Nomor 14 Tahun 2005 tentang Guru dan Dosen serta Kitab Undang-Undang Hukum Pidana untuk memberikan dasar hukum yang cukup kuat terhadap perlindungan bagi guru.

\section{Simpulan}

Modus perbuatan kekerasan terhadap guru meliputi perbuatan perundungan (bullying) yang meliputi ancaman dan serangan fisik maupun non fisik, penganiayaan maupun pembunuhan. Sementara rambu-rambu prinsip hukum pokok yang perlu diperhatikan dalam konteks penyelesaian perkara pidana terkait kasus kekerasan siswa terhadap guru meliputi dua hal yakni dari sisi siswa maupun dari sisi guru. Untuk keduanya maka berjalan dalam prinsip keseimbangan dan kesetaraan. Dari sisi siswa prinsip hak anak yang melekat pada diri individu sang siswa sebagai anak, prinsip keadilan restoratif dan serta konsep diversi menjadi hal yang

22 | Jurnal Civic Educatioan: Media Kajian Pancasila dan Kewarganegaraan 
pokok untuk diperhatikan dalam penegakan hukum atas perkara kekerasan yang dilakukan siswa terhadap guru. Selanjutnya pada sisi guru maka prinsip kesetaraan dihadapan hukum serta prinsip perlindungan atas pekerjaan maupun perlindungan atas kebebasan pribadi merupakan hal yang menjadi alasan dasar bagi adanya tindakan penegakan hukum ketika terjadi kekerasan terhadap guru oleh siswa bahkan oleh siapapun diluar siswa.

Diperlukan revisi ketentuan perundang-undangan terkait perlindungan terhadap guru sebagai sebuah profesi yang melekat pada individu tertentu. Revisi ini menjadi sebuah kebutuhan mendesak ditengah latar situasi yang kurang baik bagi guru dalam menjalankan profesinya di tengah-tengah masyarakat. Keamanan dan kenyamanan guru dalam melaksanakan tugas merupakan hal yang sangat penting untuk menjamin terlaksananya kewajiban negara dan pemerintah dalam melindungi profesi guru.

\section{Daftar Pustaka}

Anonymous. (2018). Ini Kronologis Guru Polo Diancam Bunuh Oleh Muridnya. Radar Kepahiang.

Dzuka, J., \& Dalbert, C. (2007). Student violence against teachers: Teachers' well-being and the belief in a just world. European Psychologist, 12(4), 253-260. https://doi.org/https://doi.org/10.1027/1016-9040.12.4.253

Faisal, F. Y., \& Jawade, H. (2019). Perlindungan Hukum Terhadap Profesi Guru Dalam Pelaksanaan Tugas Berdasarkan Undang-Undang Nomor 14 Tahun 2005. Deepublish.

Hadjon, P. (1987). Perlindungan Hukum Bagi Masyarakat Indonesia. Bina Ilmu.

Ikanubun, Y. (2019). Penjara 20 Tahun Menanti Siswa SMK Pembunuh Guru di Manado. Liputan6.Com.

Jajeli, R. (2018). Guru SMA di Sampang, Madura Tewas Diduga Karena Dianiaya Siswa. Detik.Com.

Kharis, U. M., \& Liany, L. (2017). Penyuluhan Perlindungan Hukum Guru dan Adab Siswa Sebagai Peserta Didik Tingkat Menengah Atas. Jurnal Balireso, 2(2).

Longobardi, C., Badenes-Ribera, L., Fabris, M. A., Martinez, A., \& McMahon, S. D. (2019). Prevalence of student violence against teachers: A meta-analysis. Psychology of Violence, 9(6).

Martono, N. (2012). Kekerasan Simbolik di Sekolah Sebuah Ide Sosiologi Pendidikan Pierre Bourdieu. Raja Grafindo Persada.

Marzuki, P. M. (2009). Penelitian Hukum. Kencana Prenada Media Group.

Moeljatno. (1984). Asas-asas Hukum Pidana (2nd ed.). Bina Aksar.

Musheer, Z., \& Shakir, M. (2017). Role of Education in the Protection and Promotion of Human rights. Research Journal of Humanities and Social Sciences, 8(3), 379. https://doi.org/10.5958/23215828.2017.00055.9

Nurhadianto, F. (2015). Sistem Hukum dan Posisi Hukum Indonesia. Jurnal TAPIs, 11(1). https://media.neliti.com/media/publications/132702-ID-sistem-hukum-dan-posisi-hukumindonesia.pdf

Paulus Hadi Suprapto, \& Atmasasmita, R. (1997). Peradilan Anak Di Indonesia. Mandar Maju.

Purbaya, A. A. (2018). Kisah Pak Guru Joko Dibully Murid-muridnya yang Jadi Viral. Detik.Com. https://news.detik.com/berita-jawa-tengah/d-4299145/kisah-pak-guru-joko-dibully-muridmuridnya-yang-jadi-viral

Purwasatria, M. U. (2019). Viralnya Kasus Bullying Siswa Terhadap Guru: Potret Buram Dunia Pendidikan. https://ayobandung.com/read/2019/02/13/44987/viralnya-kasus-bullying-siswaterhadap-guru-potret-buram-dunia-pendidikan

Putri, A. D. K., \& Imaniyati, N. (2017). Pengembangan Profesi Guru Dalam Meningkatkan Kinerja $\begin{array}{llll}\text { Guru. Pendidikan } & \text { Manajemen }\end{array}$ https://journal.unesa.ac.id/index.php/jsm/article/viewFile/1249/867

Rahardjo, S. (2000). Ilmu Hukum. Citra Aditya Bakti.

Undang-Undang Nomor 11 Tahun 2012 Tentang Sistem Peradilan Pidana Anak, (2012).

Saihu, \& Taufik. (2019). Perlindungan Hukum Bagi Guru. Al Amin: Jurnal Kajian Ilmu Dan Budaya Islam, 2(2).

Sanchez-Danday, A. S. Q. (2019). How well-protected are teachers in school? International Journal of Learning, Teaching and Educational Research, 18(6), 201-213. https://doi.org/10.26803/ijlter.18.6.12 
Soekanto, S. (2000). Penelitian Hukum Normatif: Suatu Tinjauan Singkat. PT. Raja Grafindo Persada. Soerjono, S. (1984). Pengantar Penelitian Hukum. UI Press.

Soesilo, R. (1991). Kitab Undang-Undang Hukum Pidana Serta Komentar-Komentarnya Lengkap Pasal Demi Pasal. Politea.

Soetiyono. (2005). Kejahatan Korporasi. Bayumedia.

Soetjipto, \& Kosasih, R. (2009). Profesi Keguruan. Lingkar Pena Kreativa.

Subiharta. (2015). Moralitas Hukum Dalam Hukum Praksis Sebagai Suatu Keutamaan. Jurnal Hukum Dan Peradilan, 4(3), 385-398.

Warsono, W. (2017). Guru: Antara Pendidik, Profesi, Dan Aktor Sosial. The Journal of Society \& Media, 1(1), 1. https://doi.org/10.26740/jsm.v1n1.p1-10

Zulfa, N. O., \& Zihaningrum, K. L. A. (2015). Implementasi Diversi Sebagai Wujud Perlindungan Hak Anak. Jurnal GEMA, XXVII(50). 